Süleyman Demirel Üniversitesi Fen Edebiyat Fakültesi Fen Dergisi

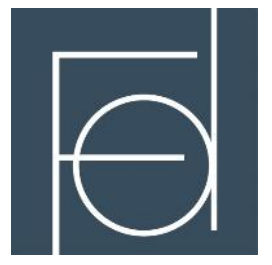

Süleyman Demirel University Faculty of Arts and Sciences Journal of Science

2021, 16(2): 500-512

DOI: $10.29233 /$ sdufeffd.1011356

Atıf için / For Citation: G, Görgülü, B, Dede, "In Silico Studies of Two Biphenyl Based

Oxime Containing Ligands”, Süleyman Demirel Üniversitesi Fen Edebiyat Fakültesi Fen Dergisi, 16(2), 500-512, 2021.

Araştırma Makalesi

\title{
In Silico Studies of Two Biphenyl Based Oxime Containing Ligands
}

\author{
Güvenç GÖRGÜLÜ ${ }^{1}$, Bülent DEDE ${ }^{* 2}$ \\ ${ }^{1}$ Mehmet Akif Ersoy University, Faculty of Education, Department of Science Education, Burdur, Türkiye \\ ${ }^{2}$ Süleyman Demirel University, Faculty of Arts and Science, Department of Chemistry, Isparta, Türkiye \\ *corresponding author e-mail: bulentdede@sdu.edu.tr
}

(Received: 19.10.2021, Accepted: 08.11.2021, Published: 25.11.2021)

\begin{abstract}
Two biphenyl based ligands were tested for their molecular docking, ADME and toxicity properties in silico. Molecular docking studies performed with two factors (VEGFR-2 and EGFRK) which are known to be effective in tumor growth. Two ligands were similar in structure except one atom difference between ligands which is $\mathrm{H}$ and $\mathrm{Cl}$. This small difference made an important impact on the molecular docking energy scores of ligand protein couples. The $\mathrm{Cl}$ atom containing ligand-protein complexes showed drastically elevated energy levels which might be due to higher electronegativity of $\mathrm{Cl}$ atom. ADME properties of two ligands were also alike except a few parameters as the inhibition of two conjugation enzymes (CYP2C19 ve CYP2C9). The biggest difference shown by the ligands were the elimination of carcinogenicity and mutagenicity of $\mathrm{H}$ containing ligand by $\mathrm{Cl}$ atom containing ligand. Druglikeness of two biphenyl based oxime containing ligands was also tested and the results of a single atom exchange were evaluated in terms of new drug design and discovery.
\end{abstract}

Key words: In Silico study, Molecular docking, ADMET, Druglikeness

\section{Oksim İçeren Bifenil Temelli İki Ligandın in silico Çalışmaları}

Öz: İki bifenil temelli ligandın moleküler kenetlenme, ADME ve toksisite özellikleri in silico olarak incelendi. Moleküler kenetlenme çalışmaları, tümör büyümesinde etkili olduğu bilinen iki faktör (VEGFR-2 ve EGFRK) kullanılarak gerçekleştirildi. İki ligand, $\mathrm{H}$ ve $\mathrm{Cl}$ olan bir atom farkı dışında yapısal açıdan benzer olarak seçildi. Bu küçük fark, ligand protein çiftlerinin moleküler kenetlenme enerji değerleri üzerinde önemli bir etki meydana getirdi. $\mathrm{Cl}$ atomu içeren ligand-protein kompleksleri, $\mathrm{Cl}$ atomunun daha yüksek elektronegatifliğinden kaynaklanabilecek büyük enerji değerlerine sahip olarak bulundu. İki konjugasyon enziminin (CYP2C19 ve CYP2C9) inhibisyonu gibi birkaç parametre dışında iki ligandın ADME özelliklerinin benzer olduğu belirlendi. Ligandların gösterdiği en büyük farkın, H içeren ligandın kanserojenliğinin ve mutajenitesinin $\mathrm{Cl}$ atomu içeren ligand ile ortadan kaldırması olduğu tespit edildi. İki bifenil bazlı oksim içeren ligandın ilaç benzerliği de test edildi ve tek bir atom değişiminin sonuçları, yeni ilaç tasarımı ve keşfi açısından değerlendirildi.

Anahtar kelimeler: In Silico çalışma, Moleküler kenetlenme, ADMET, İlaçbenzerlik 


\section{Introduction}

Computer-aided drug design (CADD) is used for the rapid assessment of chemical databases to accelerate the early-stage development of new active compounds [1]. CADD can be structure or ligand originated which is essentially based on the chemical similarity to active compounds used [2,3]. This preliminary study relies on the elimination of the unrelated and vastly reducing the number of molecules to be studied. The typical role of CADD in drug discovery is to screen out large compound libraries into smaller clusters of predicted active compounds enabling optimization of lead compounds and by improving the biological properties and building chemotypes from a nucleating site by combining fragments with optimized function.

Among the CADD researches molecular docking studies comprise the major part in the preliminary studies. A designed ligand molecule can be tested for its binding capacity by picking up the optimal data for binding energy, fitness score, optimized energy of the complex (ligand \& target molecule) with molecular docking study. The study also gives the number and location of possible hydrogen bonds formed. Plus, all binding poses are obtained as charming graphical data showing the proximity and orientation of the ligand molecule to the target protein [4].

Pharmacokinetics is the quantitative study of drug movement in and through the body expressed as the absorption, distribution, metabolism, excretion and toxicity (ADMET). Major elimination of the candidate molecules is achieved through molecular docking and pharmacokinetic studies $[5,6]$.

Oxime containing compounds are extensively synthesized and characterized due to their coordination capacity which plays a major role in their chemical, biological, pharmacological and industrial capacity $[7,8]$. Since many oxime derivatives are still in use as pharmacological agents, it has become more important for new analogous compounds being synthesized, characterized and tested for druglikeness and toxicity. During these processes some new compounds will be extinguished and most of them will be eliminated.

Angiogenesis is one of the major factors in tumor growth and metastasis with a sequential mechanism. VEGFR-2 (vascular endothelial growth factor receptor-2) is often used as a parameter for being a potent tumorigenic and metastatic factor due to its angiogenic and lymphangiogenic effects [9]. Similarly, high expression levels of EGFRK (tyrosine kinase domain from the epidermal growth factor receptor) have been frequently observed in breast, prostate, ovarian and various squamous cell carcinomas in which overexpression positively correlates with shortened survival times and increased relapse rates [10].

VEGFR-2 and EGFRK show synergistic effects in tumor growth which makes them precise monitoring factors for cancer. Therefore, the inhibition of these carcinogenic factors became important. For this purpose, two of the previously designed, synthesized and characterized biphenyl based oxime containing ligands [11-13], namely; biphenyl4-yl-oxo-acetaldehyde oxime (BHKO) and biphenyl-4-yl-oxo-chloro oxime (BCKO) were investigated for their molecular docking behaviors for VEGFR-2 and EGFRK. Revealing the binding properties of these two ligands to the VEGFR-2 expected to give valuable information about the antagonistic effects to the factor, in particular. Ligands were also tested for their ADMET properties. 


\section{Material and Method}

Molecular docking studies were performed on SwissDock web server using EADock DSS algorithm [14]. High resolution crystal structures of VEGFR-2 (PDB ID: 2XIR) and EGFRK (PDB ID:1M17) were obtained from protein data bank (https://www.rcsb.org/). All visualizations of molecular docking studies were performed using UCSF Chimera software [15]. The GaussView 5.0.9 program was used to visualize the optimized geometries of the ligands [16]. ADME properties were executed by SwissADME web server to compile the information on the pharmacokinetics and pharmacodynamics of candidate molecules [17]. In addition, ligands were tested for their toxicity by ProTox-II web server [18].

\section{Results}

\subsection{Molecular Docking Studies}

Molecular docking simulations of the biphenyl derivatives were performed to understand in detail the various interactions between ligand and protein. Molecular docking studies started with the optimization of candidate ligands. In order to prepare the biphenyl derivatives for docking studies, their energies were minimized using the molecular mechanical method. On the other hand, waters and co-crystallized ligands were removed from the 3D crystal structures of the proteins. In addition, Kollman and Gastegier charges were calculated and polar hydrogens were added. Figure 1 shows the structures of biphenyl based BHKO and BCKO ligands.
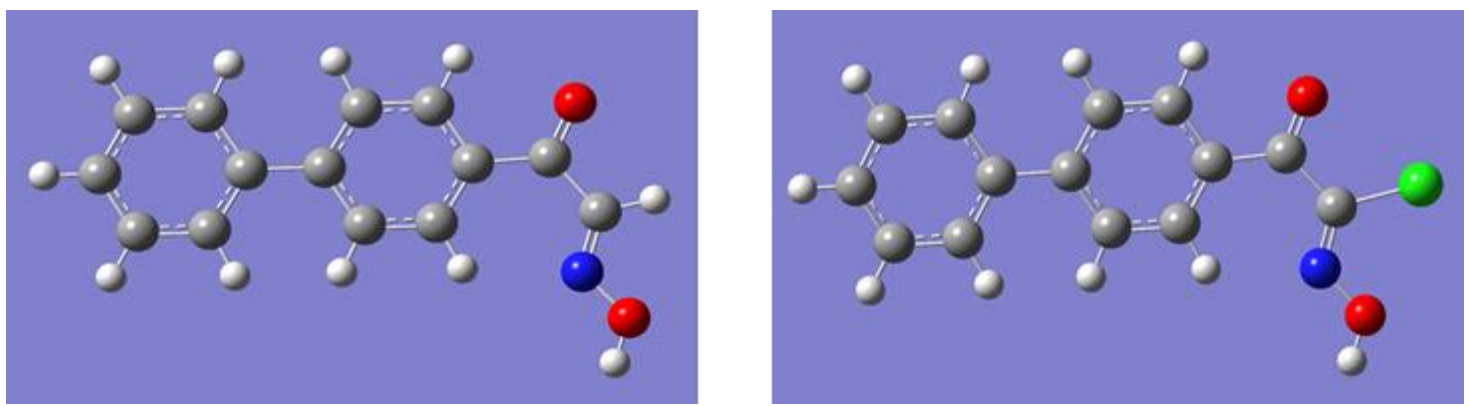

Figure 1. Optimized structures of BHKO (left) and BCKO (right) ligands

Both ligands were docked with VEGFR-2 and EGFRK proteins. Among a number of conformations, ligand-protein complexes with a higher number of formed hydrogen bonds, relatively higher full fitness scores and higher Gibbs free energies were chosen. The results were shown in Table 1.

Table 1. The molecular docking scores of ligand-protein chosen couples

\begin{tabular}{|c|l|c|c|c|c|c|}
\hline $\begin{array}{c}\text { TARGET } \\
\text { PROTEIN }\end{array}$ & LIGAND & $\begin{array}{c}\Delta \mathbf{G} \\
(\mathbf{k c a l} / \mathbf{m o l})\end{array}$ & $\begin{array}{c}\text { FULL } \\
\text { FITNESS } \\
\text { SCORE } \\
(\mathbf{k c a l} / \mathbf{m o l})\end{array}$ & $\begin{array}{c}\text { ENERGY } \\
(\mathbf{k c a l} / \mathbf{m o l})\end{array}$ & $\begin{array}{c}\text { H-BOND } \\
\text { LOCATION } \\
\text { (Target\&Ligand) }\end{array}$ & $\begin{array}{c}\text { H-BOND } \\
\text { LENGTH } \\
(\AA)\end{array}$ \\
\hline \multirow{2}{*}{$\begin{array}{c}\text { VEGFR-2 } \\
(\mathbf{2 X I R )}\end{array}$} & $\mathbf{B H K O}$ & -7.34 & -1595.24 & 19.85 & $\begin{array}{c}\text { Asp 1046 -HN \& } \\
\text { carbonyl O }\end{array}$ & 2.23 \\
\cline { 2 - 7 } & $\mathbf{B C K O}$ & -7.31 & -1574.57 & 26.62 & $\begin{array}{c}\text { Leu 1049 -HN \& } \\
\text { oxime N }\end{array}$ & 2.39 \\
\hline \multirow{2}{*}{$\begin{array}{c}\text { EGFRK } \\
(\mathbf{1 M 1 7})\end{array}$} & $\mathbf{B H K O}$ & -6.97 & -2174.56 & 14.60 & $\begin{array}{c}\text { Cys 773 -HN \& } \\
\text { oxime O }\end{array}$ & 2.31 \\
\cline { 2 - 7 } & $\mathbf{B C K O}$ & -6.90 & -2150.34 & 29.21 & $\begin{array}{c}\text { Cys 773 -HN \& } \\
\text { oxime O }\end{array}$ & 2.21 \\
\hline
\end{tabular}


Gibbs free energy of BHKO and BCKO ligands with VEGFR-2 protein has similar results as -7.34 and $-7.31 \mathrm{kcal} / \mathrm{mol}$, respectively. These data reveals that the reactions between the ligand and target were spontaneous. The two ligands coupled with the target proteins showed similar data in Gibbs free energies, full fitness scores and hydrogen bond lengths while the total energy of the molecules were vastly increased in BCKO-target couple which only differs with BHKO-target couple by the presence of an electronegative $\mathrm{Cl}$ atom instead of $\mathrm{H}$. From the data, BHKO-VEGFR-2 couple seemed much more stable compared to BCKO-VEGFR-2 couple. The situation becomes more distinct for the BCKO-EGFRK couple which has twice as higher energy as the BHKOEGFRK couple has. Figure 2 shows the ribbon shaped and space filled models for BHKO-VEGFR-2 couple with closer views. Green lines represent the hydrogen bonding between the protein and ligand.
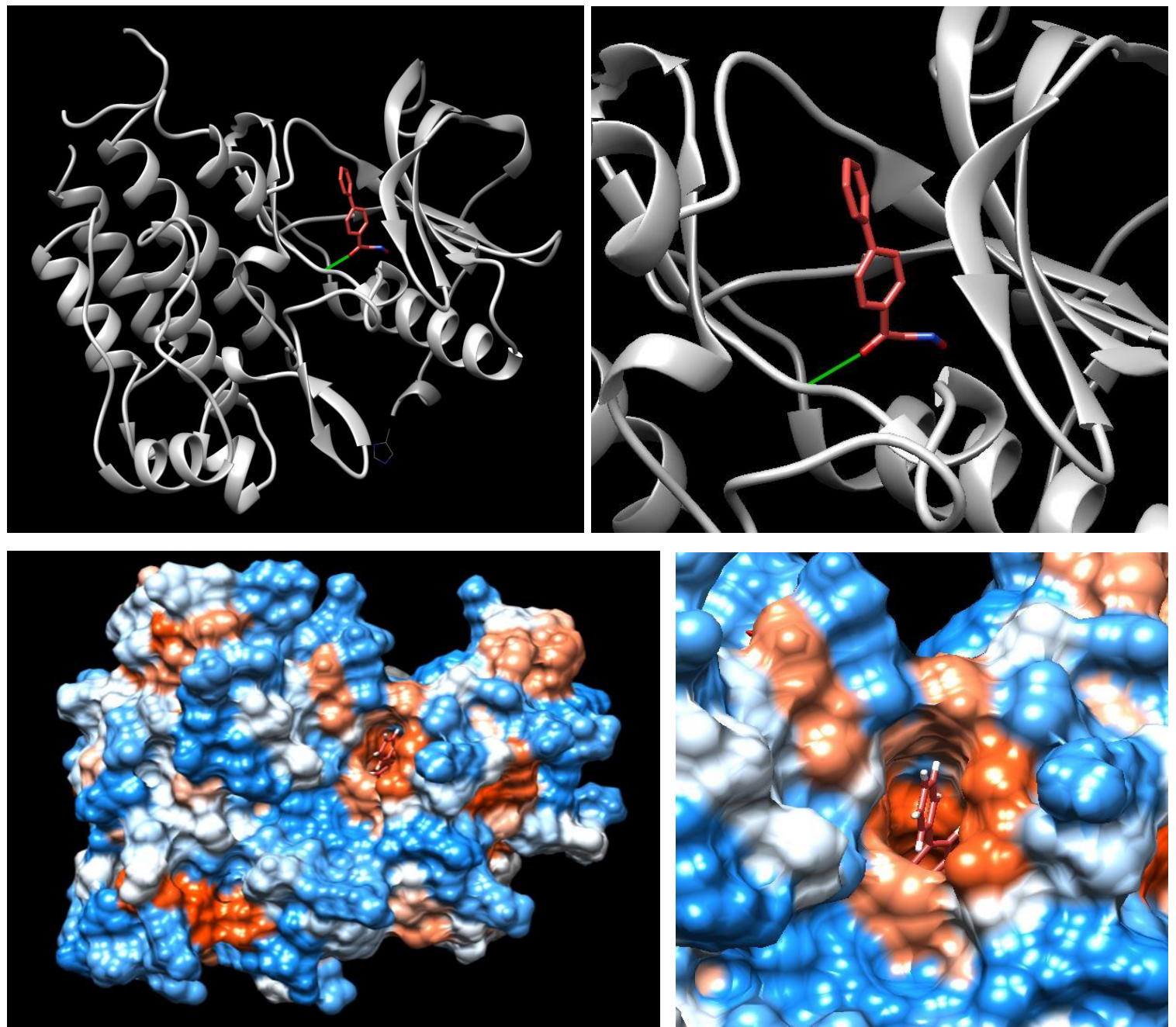

Figure 2. Ribbon shaped (above) and space filled (below), full (left) and closer (right) views for BHKOVEGFR-2 couple.

The data obtained and space-filled model views shows that BHKO ligand was docked with a high proximity in VEGFR-2 protein as seen from the Figure 2. The hydrogen bond was formed between the hydrogen of -HN group of amino acid $1046^{\text {th }}$ (aspartic acid) and $\mathrm{O}$ of carbonyl group of the ligand. The pose of the most stable complex simulated between BHKO and EGFRK is given in Figure 3. In this complex, the calculated hydrogen bond with a length of $2.31 \AA$ was found between -HN group of Cys 773 and oxime $\mathrm{O}$ of the ligand. 

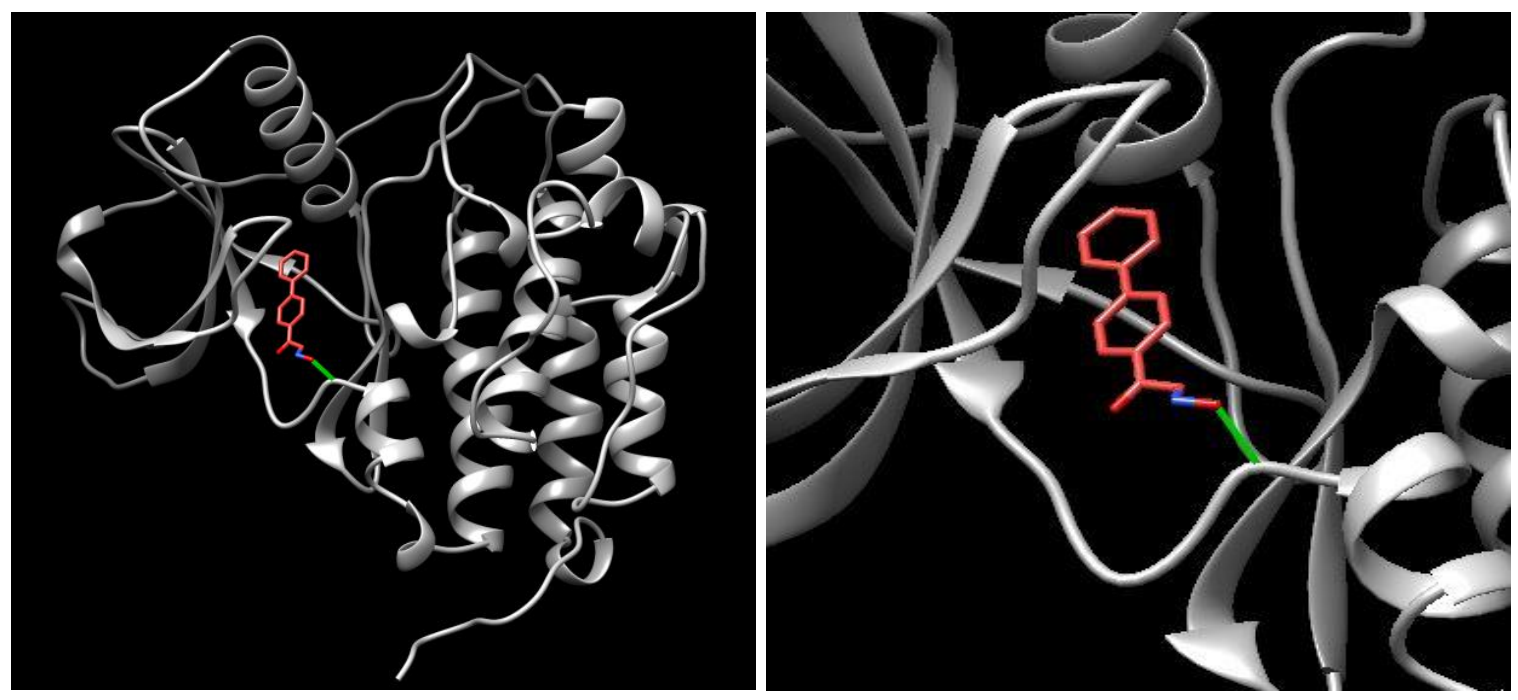

Figure 3. BHKO-1M17 couple; full (left) and closer view (right)
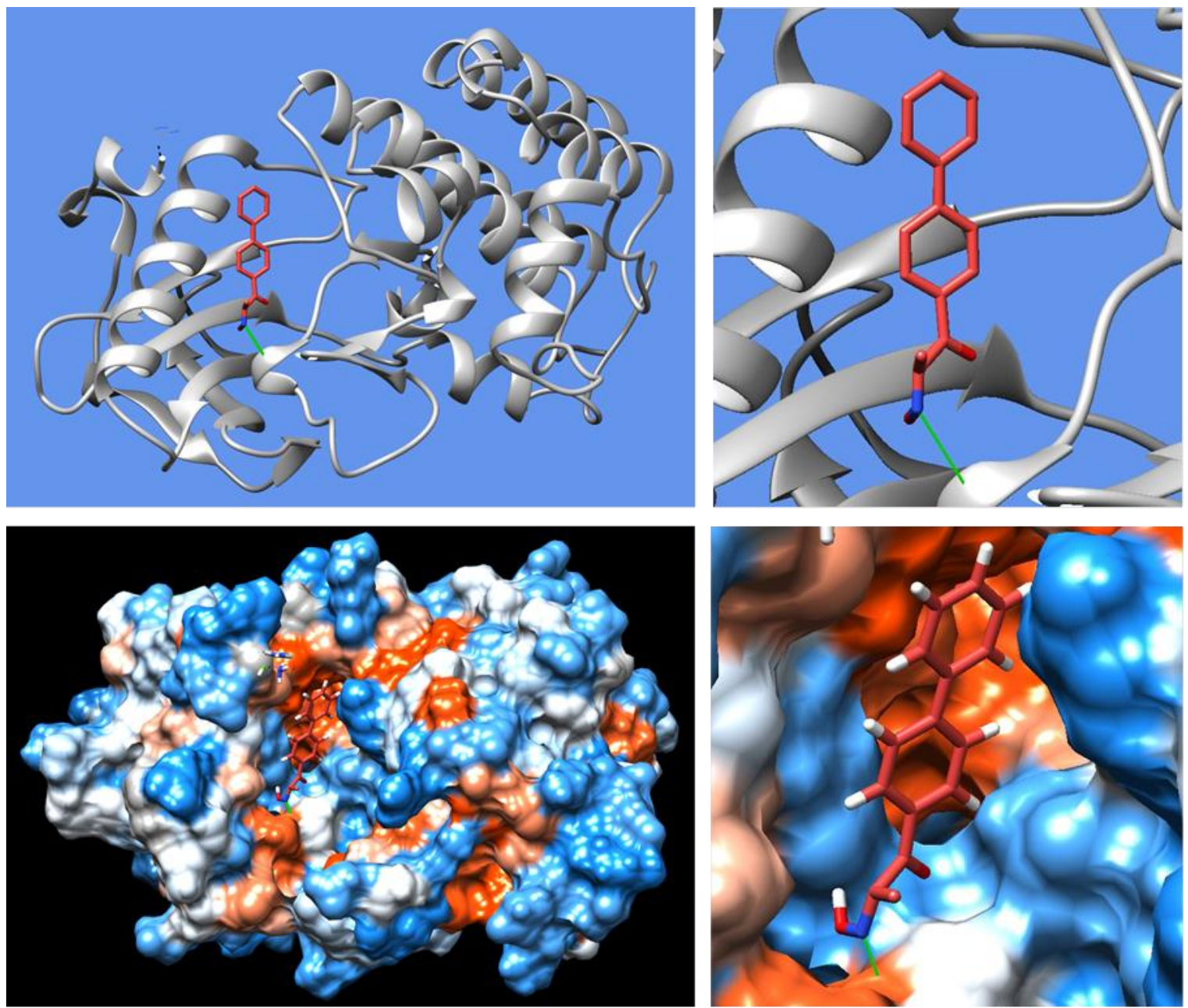

Figure 4. Ribbon shaped (above) and space-filled (below), full (left) and closer (right) views for BCKOVEGFR-2 couple. Green line represents the hydrogen bond formed between BCKO and VEGFR-2.

In Figure 4 space-filled model (below) the red area corresponds to negative and the blue area is positive. The hydrogen bond formed between the ligand and VEGFR-2 protein is shown in green color. The hydrogen bond was formed between the hydrogen of -HN group of $1049^{\text {th }}$ amino acid leucine and oxime nitrogen of the ligand. 
Not all the visuals related to the data in Table 1 were put in the manuscript for simplicity. Also, BHKO coupled figures kept with black background while BCKO coupled ones are kept with blue for the same reason.

\subsection{ADME Studies}

Biphenyl based ligands were tested for ADME by SwissADME web server to compile the information on the pharmacokinetics and pharmacodynamics of candidate molecules. In addition, these ligands were tested for toxicity by ProTox-II web server.

Table 2. ADME table showing the physicochemical properties of BHKO (above) and BCKO (below) ligands

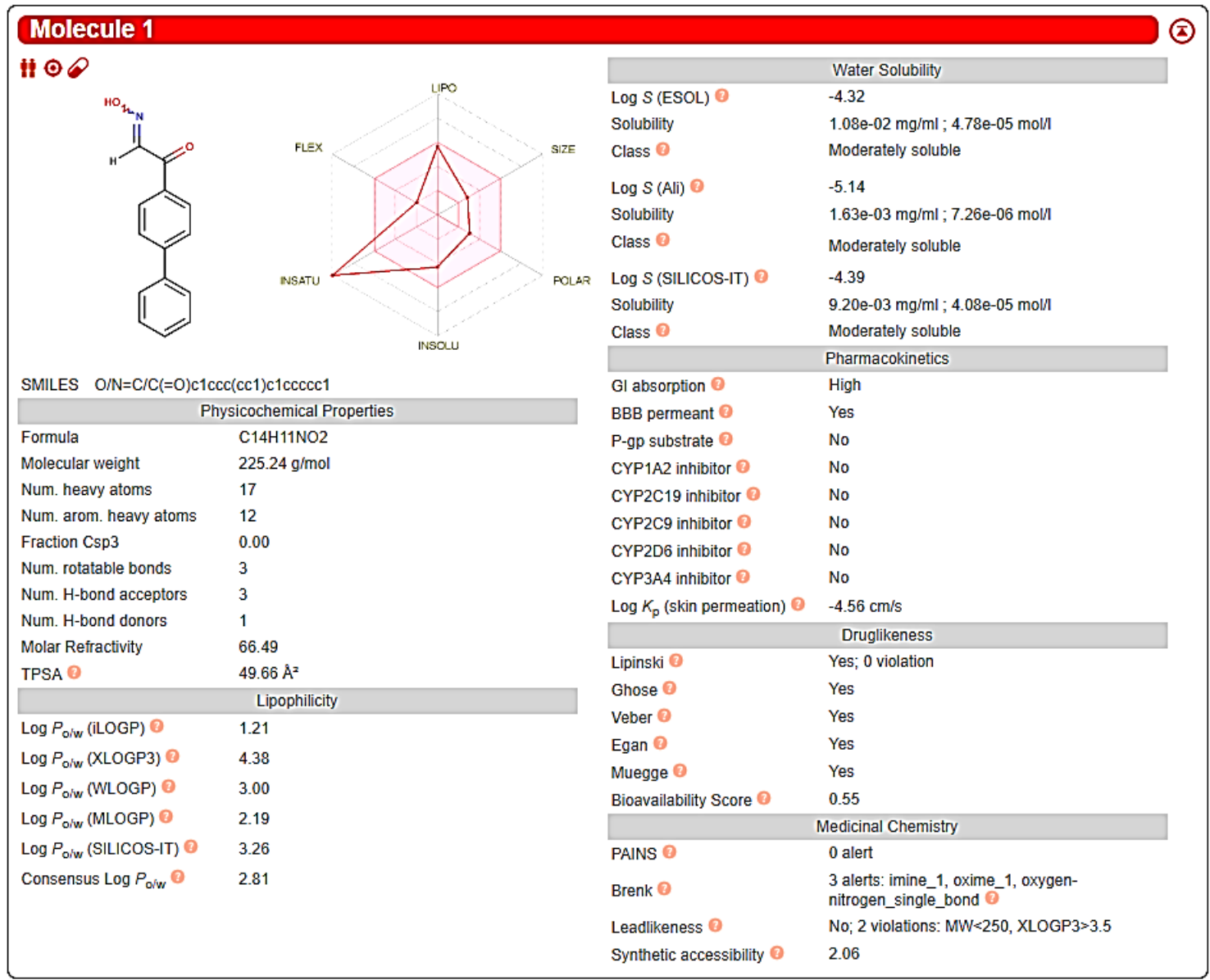




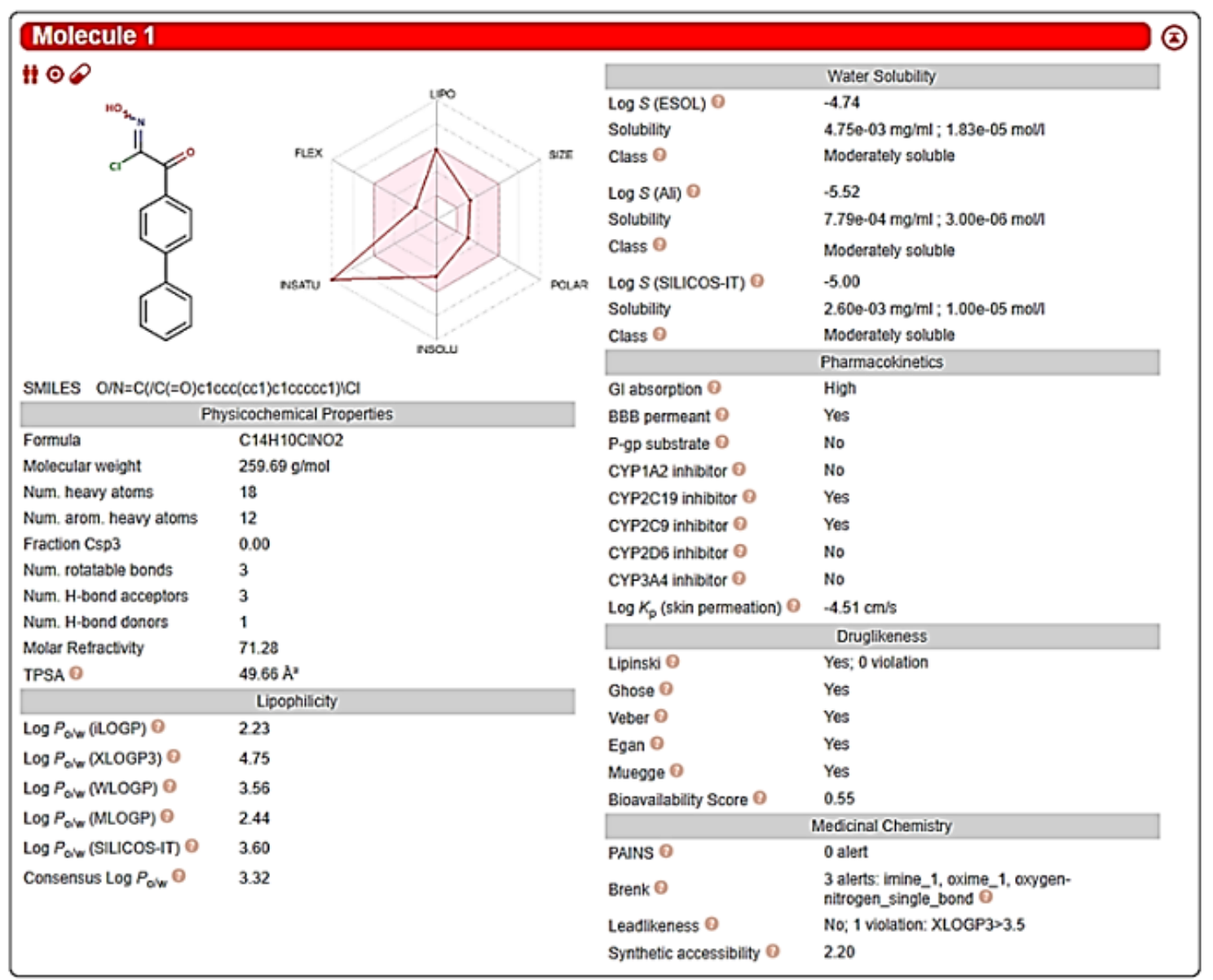

As the radar chart shows five of the six rules for druglikeness were provided by both of the executed ligands according to the SwissADME predictions. The INSATU violation in the radar chart refers to the ratio of $\mathrm{sp}^{3}$ hybridized of $\mathrm{C}$ atoms to the total number of $\mathrm{C}$ atoms. No $\mathrm{C}$ atoms have sp3 hybridization for both ligands; therefore, the Csp3 fraction was zero as seen in Table 2. The official paper of SwissADME [14] also stated; for any deviation of the radar chart has been represented a suboptimal physicochemical property for oral bioavailability. Even the terms oral absorption and oral bioavailability do not refer the same meaning they are frequently used interchangeably by highly respected and cited publications. They also seem strictly correlated including the transit time (gut wall and liver passing times) to the calculations [19]. In our case a deviation from the pink area with INSATU value of SwissADME radar chart seems to make our ligand useless. We used another formula to calculate the percentage absorption of our ligand based on the PSA (polar surface area) method [20]. The percentage absorption value of the both ligands was obtained as $91.87 \%$ which may eliminate the inconvenience on the druglikeness of our ligands. In addition, both ligands provide the Lipinski's rule of five with zero violation as shown in Table 2 and 3. 
Table 3. Physicochemical properties of BHKO and BCKO ligands subjected to Lipinski's Rule of Five

\begin{tabular}{|c|c|c|c|c|c|c|}
\hline \multicolumn{7}{|c|}{ Physicochemical Properties } \\
\hline & \multicolumn{7}{|c|}{ LIPINSKI'S RULE of FIVE } \\
& $\begin{array}{c}\text { TPSA } \\
\left(\AA^{2}\right)\end{array}$ & $\begin{array}{c}\text { Consensus } \\
\text { Log } \mathrm{P}_{\mathrm{o} / \mathrm{w}}\end{array}$ & $\begin{array}{c}\mathrm{MW} \\
(\mathrm{g} / \mathrm{mol}) \\
\leq 500\end{array}$ & $\begin{array}{c}\text { Log } \mathrm{P}_{\mathrm{o} / \mathrm{w}} \\
(\mathrm{ML}) \\
\leq 4.15\end{array}$ & $\begin{array}{c}\text { H Bond } \\
\text { Donor Atoms } \\
\leq 10 \\
(\mathrm{~N} \text { or O })\end{array}$ & $\begin{array}{c}\text { H Bond } \\
\text { Acceptor Atoms } \\
\leq 5 \\
(\mathrm{NH} \text { or OH })\end{array}$ \\
\hline BHKO & 49.66 & 2.81 & 225.24 & 2.19 & 1 & 3 \\
\hline BCKO & 49.66 & 3.32 & 259.69 & 2.44 & 1 & 3 \\
\hline
\end{tabular}

In Table 2, pharmacokinetics part BHKO does not interact any of the conjugation enzymes while BCKO inhibits two of them which are CYP2C19 and CYP2C9. This is probably due to the electronegative $\mathrm{Cl}$ atom in $\mathrm{BCKO}$ which is again the only difference between two ligands.

Both ligands show high absorption rates. In Figure 5, the red plot in the middle of egg yolk shows the ligands can pass blood-brain barrier (BBB) besides the human gastrointestinal absorption (HIA). The red color of the dot refers to the info that the ligand is not a substrate for P-glycoprotein (shown as PGP-) which is an important criterion for pharmacokinetics [21]. The model was formed by plotting WLOGP vs. TPSA (lipophilicity vs. topological polar surface area) in a boiled egg model which shows the passive absorptive states. Egg orientation in the analytical coordinate also gives information about the acceptable values for WLOGP and TPSA. For BHKO and $\mathrm{BCKO}$ ligands both red dots located in the middle part of yolk revealing that they have the highest absorptive states for HIA and BBB.
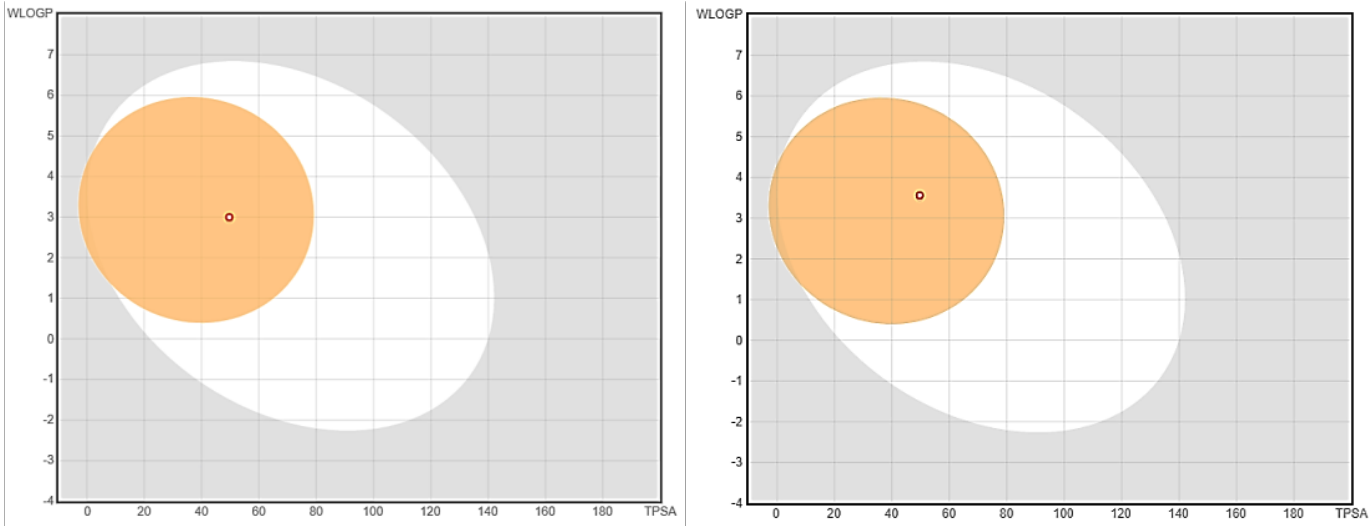

Figure 5. BOILED-Egg model for BHKO (left) and BCKO (right) ligands which refer to the predictions for human gastrointestinal absorption (HIA) and blood-brain barrier (BBB) permeation 


\subsection{Toxicological Studies}

Both ligands were tested for a detailed toxicity profile. Table 4 shows a general profile for the executed molecules. $\mathrm{LD}_{50}$ and toxicity class of the ligands are seen in the middle. Also the similarity of the interested molecules with the molecules in the database are compared and resulted as the average similarity. Accuracy of the software is also predicted. The geometry and the identification of the molecules are also given in Table 4.

Table 4. Oral toxicity predictions for BHKO (above) and BCKO (below) ligands

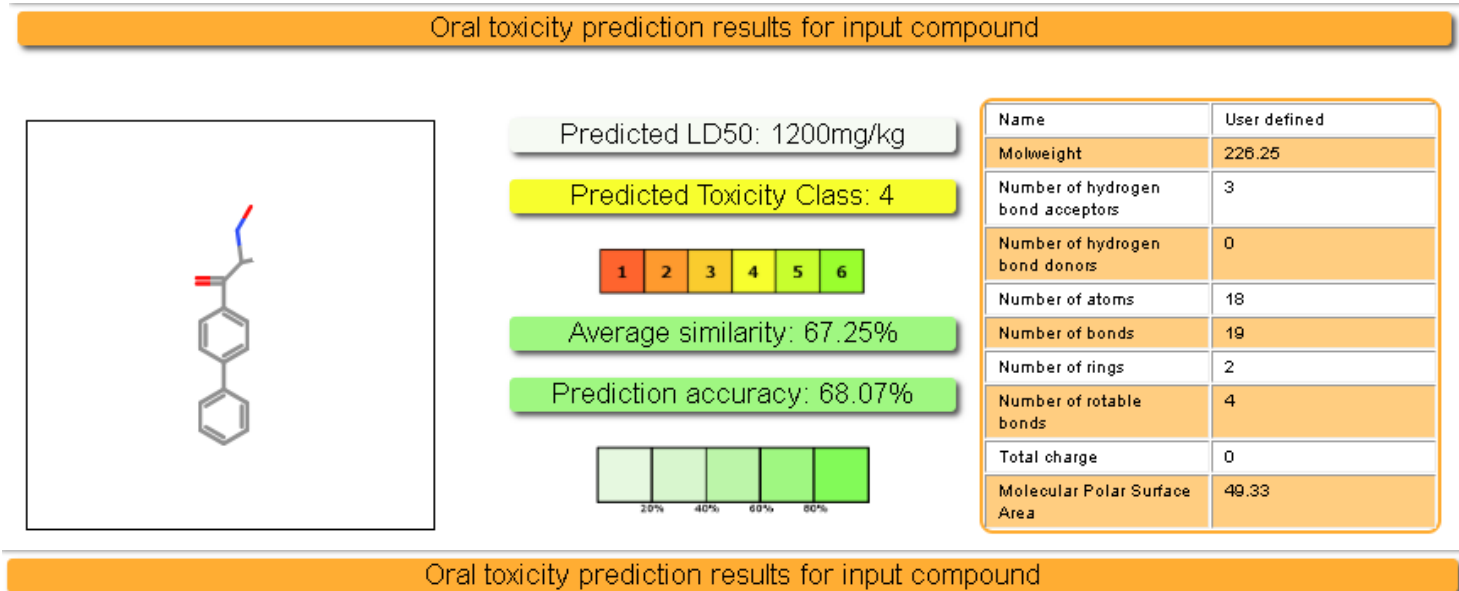

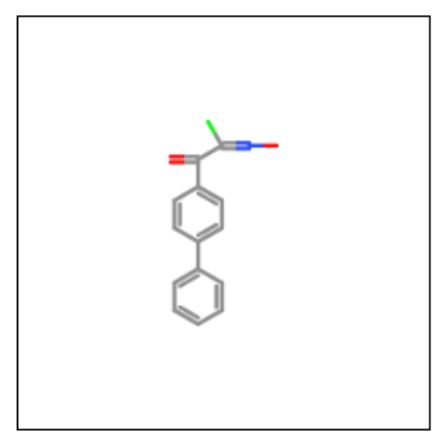

\begin{tabular}{|c|c|c|c|c|c|c|c|}
\hline \multirow{2}{*}{\multicolumn{6}{|c|}{ Predicted LD50: $2000 \mathrm{mg} / \mathrm{kg}$}} & Name & User defined \\
\hline & & & & & & Molweight & 259.69 \\
\hline \multicolumn{6}{|c|}{ Predicted Toxicity Class: 4} & $\begin{array}{l}\text { Number of hydrogen } \\
\text { bond acceptors }\end{array}$ & 3 \\
\hline 1 & 2 & \multirow{2}{*}{3} & \multirow{2}{*}{4} & \multirow{2}{*}{\multicolumn{2}{|c|}{5}} & $\begin{array}{l}\text { Number of hydrogen } \\
\text { bond donors }\end{array}$ & 0 \\
\hline \multirow{2}{*}{\multicolumn{6}{|c|}{ Average similarity: $58.31 \%$}} & Number of atoms & 18 \\
\hline & & & & & & Number of bonds & 19 \\
\hline \multirow{2}{*}{\multicolumn{6}{|c|}{ Prediction accuracy: $67.38 \%$}} & Number of rings & 2 \\
\hline & & & & & & $\begin{array}{l}\text { Number of rotable } \\
\text { bonds }\end{array}$ & 3 \\
\hline \multirow{2}{*}{ 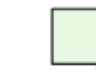 } & & & & & & Total charge & 0 \\
\hline & & & & & & $\begin{array}{l}\text { Molecular Polar Surface } \\
\text { Area }\end{array}$ & 49.66 \\
\hline
\end{tabular}

In Table 4 both ligands were sketched and predicted for $\mathrm{LD}_{50}$ which is higher for $\mathrm{BCKO}$ ligand but the range they resided is Toxicity Class 4 for both ligands. Not significantly, $\mathrm{BCKO}$ is less toxic. Both ligands also share similar molecular properties with an only exchange in $\mathrm{Cl}$ and $\mathrm{H}$ atoms. 
Distribution of molweight
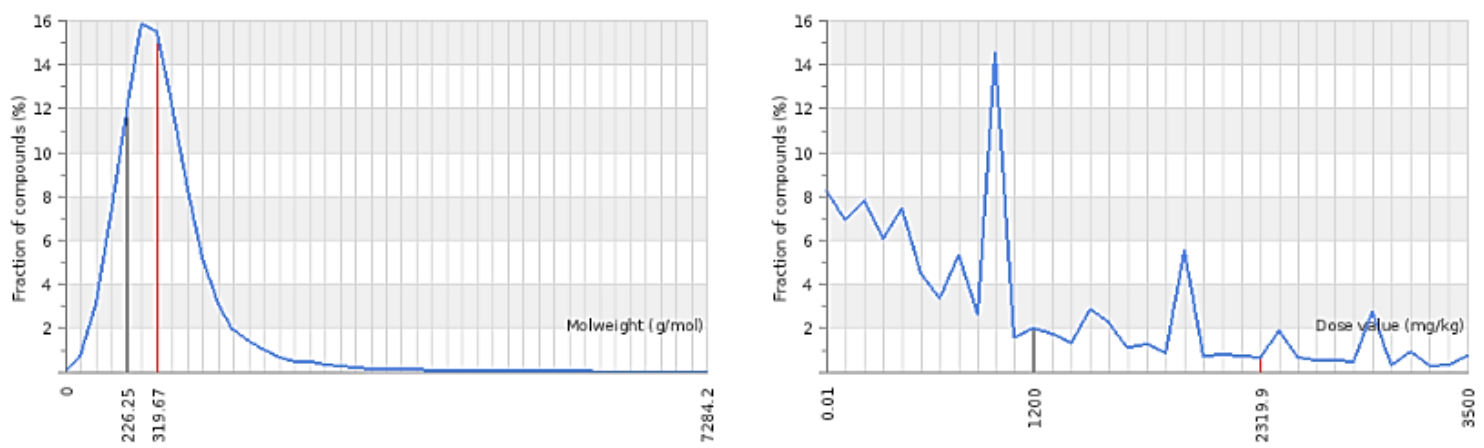

alue of input compound

Mean value of dataset

Distribution of molweight

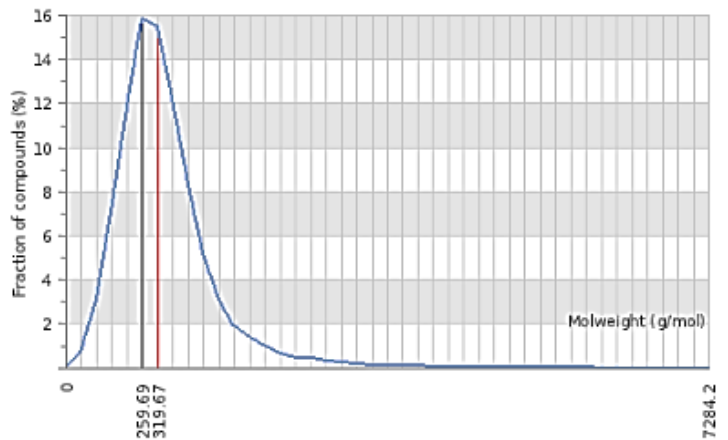

Distribution of dose value

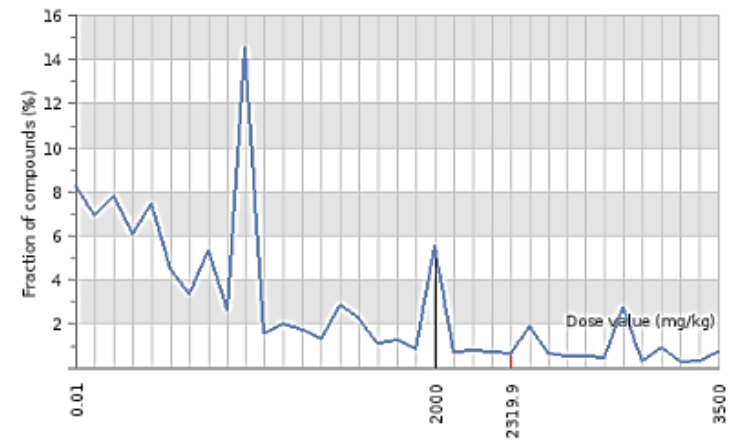

Figure 6. The molecular weight and administrated dose of BHKO (left) and BCKO (right) are compared with the commercially active agents' average molecular weight and dose.

In Figure 6 mean values of molecular weights and dose values for the commercial agents in the market (limited to the agents in the database of ProTox-II) are compared to the molecule of interest. Both ligands' molecular weight and dose values were below the mean value of dataset. 
Table 5. Toxicity test results of the BHKO (above) and BCKO (below) ligand in toxicologically important parameters

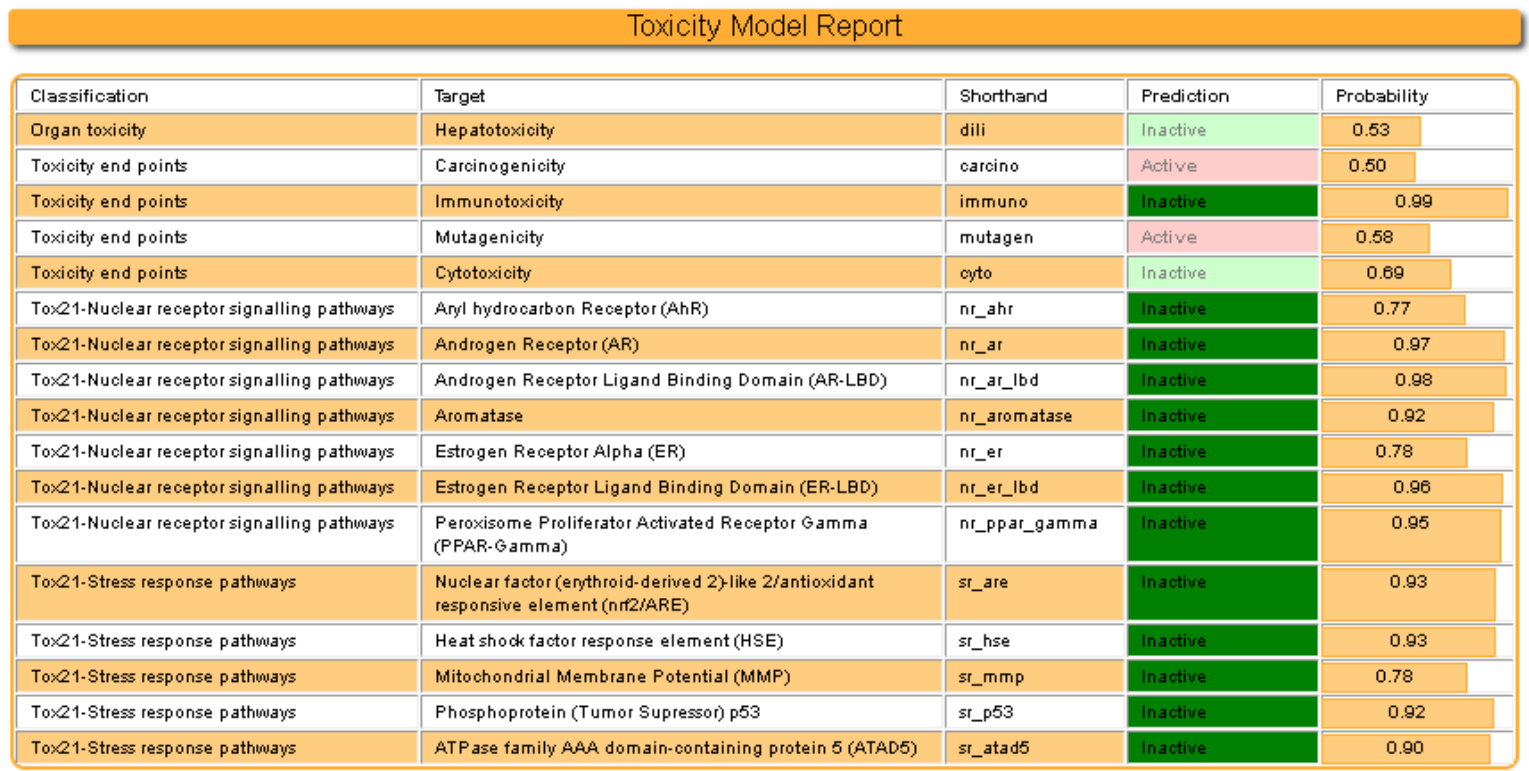

\begin{tabular}{|c|c|c|c|c|}
\hline \multicolumn{5}{|c|}{ Toxicity Model Report } \\
\hline Classification & Target & Shorthand & Prediction & Probability \\
\hline Organ toxicity & Hepatotoxicity & dili & Active & 0.55 \\
\hline Toxicity end points & Carcinogenicity & carcino & Inactive & 0.51 \\
\hline Toxicity end points & Immunotoxicity & immuno & Inactive & 0.98 \\
\hline Toxicity end points & Mutagenicity & mutagen & Inactive & 0.58 \\
\hline Toxicity end points & Cytotoxicity & cyto & Inactive & 0.75 \\
\hline Tox21-Nucle ar receptor signalling pathways & Anyl hydrocarbon Receptor (AhR) & nr_ahr & Inactive & 0.67 \\
\hline To $\times 21$-Nucle ar receptor signalling pathways & Androgen Receptor (AR) & ni_ar & Inactive & 0.96 \\
\hline To 21 -Nuclear receptor signalling pathways & Androgen Receptor Ligand Binding Domain (AR-LBD) & ni_ar_lbd & Inactive & 0.96 \\
\hline To $\times 21$-Nucle ar receptor signalling pathways & Aromatase & ni_aromatase & Inactive & 0.85 \\
\hline To $\times 21$-Nucle ar receptor signalling pathways & Estrogen Receptor Alpha (ER) & ni_er & Inactive & 0.74 \\
\hline To 21 -Nuclear receptor signalling pathways & Estrogen Receptor Ligand Binding Domain (ER-LBD) & ni_er_lbd & Inactive & 0.86 \\
\hline Tox21-Nuclear receptor signalling pathways & $\begin{array}{l}\text { Peroxisome Proliferator Activated Receptor Gamma } \\
\text { (PPAR-Gamma) }\end{array}$ & nr_ppar_gamma & Inactive & 0.90 \\
\hline To 21 -Stress response pathways & $\begin{array}{l}\text { Nuclear factor (erythroid-derived 2)-like } 2 / \text { antioxidant } \\
\text { responsive element (nrrz/ARE) }\end{array}$ & st_are & Inactive & 0.84 \\
\hline To $\times 21$-Stress response pathways & Heat shock factor response element (HSE) & sr_hse & Inactive & 0.84 \\
\hline To 21 -Stress response pathways & Mitochondrial Membrane Potential (MMP) & st_mmp & Inactive & 0.59 \\
\hline To $\times 21$-Stress response pathways & Phosphoprotein (Tumor Supressor) p 53 & st_p53 & Inactive & 0.83 \\
\hline To $\times 21$-Stress response pathways & ATP ase family AAA domain-containing protein 5 (ATAD5) & st_atad5 & Inactive & 0.74 \\
\hline
\end{tabular}

In Table 5; toxicologically important parameters were interpreted. BHKO ligands' carcinogenicity and mutagenicity is $50 \%$ and $58 \%$ active where the mean value of the dataset is given as $88 \%$ and $79 \%$, respectively. All other parameters were inactive for BHKO ligand. For BCKO only hepatotoxicity was $55 \%$ active where the mean value for the drugs in the market was given as $82 \%$.

\section{Conclusion and Comment}

The molecular docking capacities of both ligands were similar. The carcinogenic effect in the BHKO ligand was eliminated by the $\mathrm{H} \& \mathrm{Cl}$ exchange. As we stated before, the only difference between ligands were $\mathrm{Cl}$ replaced by $\mathrm{H}$ atom. This is a huge difference for a drug candidate having carcinogenic and mutagenic effects which can be eliminated by a "click" movement indicating the importance of the redesign of the drugs. Drug resistance and side effects can be eliminated by the reconstruction of the drugs already on the market. 


\section{Author Statement}

Güvenç GÖRGÜLÜ: Investigation, Software, Visualization, Original Draft Writing, Review and Editing. Bülent DEDE: Methodology, Original Draft Writing, Review and Editing.

\section{Acknowledgment}

As the authors of this study, we declare that we do not have any support and thank you statement.

\section{Conflict of Interest}

As the authors of this study, we declare that we do not have any conflict of interest statement.

\section{Ethics Committee Approval and Informed Consent}

As the authors of this study, we declare that we do not have any ethics committee approval and/or informed consent statement.

\section{References}

[1] D. G. Truhlar, W. J. Howe, A. J. Hopfinger, J. Blaney, R. A. Dammkoehler, Rational Drug Design. New York: Springer, 1999.

[2] C. Liao, M. Sitzmann, A. Pugliese, M. C. Nicklaus, "Software and resources for computational medicinal chemistry," Future Medicinal Chemistry, 3(8), 1057-1085, 2011.

[3] G. D. Geromichalos, C. E. Alifieris, E. G. Geromichalou, D. T. Trafalis, "Overview on the current status of virtual high-throughput screening and combinatorial chemistry approaches in multi-target anticancer drug discovery; Part I," Journal of BUON, 21(4), 764-779, 2016.

[4] O. Gürsoy, M. Smieško, "Searching for bioactive conformations of drug-like ligands with current force fields: how good are we?," Journal of Cheminformatics, 9(1), 1-13, 2017.

[5] J. Vrbanac, R. Slauter, ADME in drug discovery. In A Comprehensive Guide to Toxicology in Nonclinical Drug Development, Academic Press, 2017, pp. 39-67.

[6] B. Chandrasekaran, S. N. Abed, O. Al-Attraqchi, K. Kuche, R. K. Tekade, Computer-aided prediction of pharmacokinetic (ADMET) properties. In Dosage form design parameters, Academic Press, 2018, pp. 731-755.

[7] D. Premužić, A. Filarowski, M. Hołyńska, "Structure and properties of a new rigid tripodal oxime ligand," Journal of Molecular Structure, 1136, 100-106, 2017.

[8] Ashani Y., Silman I. 2010. Hydroxylamines and oximes: Biological properties and potential uses as therapeutic agents, John Wiley \& Sons, Ltd.

[9] N. Ferrara, H. P. Gerber, J. LeCouter, "The biology of VEGF and its receptors," Nature Medicine, 9(6), 669-676, 2003.

[10] D. W. Fry, A. J. Bridges, W. A. Denny, A. Doherty, K. D. Greis, J. L. Hicks, K. E. Hook, P. R. Keller, W. R. Leopold, J. A. Loo, D. J. McNamara, J. M. Nelson, V. Sherwood, J. B. Smaill, S. Trumpp-Kallmeyer, E. M. Dobrusin, "Specific, irreversible inactivation of the epidermal growth factor receptor and erbB2, by a new class of tyrosine kinase inhibitor," Proceedings of the National Academy of Sciences of the USA, 95(20), 12022-12027, 1998.

[11] I. Karataş, H. I. Uçan, "The synthesis of biphenylglyoxime and bis (phenylglyoxime) and their complexes with $\mathrm{Cu}(\mathrm{II}), \mathrm{Ni}(\mathrm{II})$ and $\mathrm{Co}(\mathrm{II})$, , Synthesis and Reactivity in Inorganic and Metal-Organic Chemistry, 28(3), 383-391, 1998.

[12] N. Levin, W. H. Hartung, "Amino alcohols. XI. ${ }^{1}$ Arylglyoxylohydroxamyl chlorides ${ }^{2}$," The Journal of Organic Chemistry, 7(5), 408-415, 1942.

[13] D. S. Breslow, K. Brack, H. Boardman, “A one-component sealant based on 1, 3-dipoles,” Journal of Applied Polymer Science, 32(4), 4657-4661, 1986.

[14] A. Grosdidier, Z. Vincent, M. Olivier, "Swissdock, A protein-small molecule docking web service based on EADock DSS," Nucleic Acids Research, 39(2), 270-277, 2011.

[15] E. F. Pettersen, T. D. Goddard, C. C. Huang, G. S. Couch, D. M. Greenblatt, E. C. Meng, T. E. Ferrin, "UCSF Chimera-a visualization system for exploratory research and analysis," Journal of Computational Chemistry, 25(13), 1605-1612, 2004. 
[16] GaussView, Revision 5.0.9, R. Dennington, T. A. Keith, J. M. Millam, Semichem Inc., Shawnee Mission, KS, 2009.

[17] A. Daina, O. Michielin, V. Zoete, "SwissADME: a free web tool to evaluate pharmacokinetics, drug-likeness and medicinal chemistry friendliness of small molecules," Scientific Reports, 7(1), 113, 2017.

[18] P. Banerjee, A. O. Eckert, A. K. Schrey, R. Preissner, "ProTox-II: a webserver for the prediction of toxicity of chemicals," Nucleic Acids Research, 46(W1), W257-W263, 2018.

[19] W. L. Chiou, "The rate and extent of oral bioavailability versus the rate and extent of oral absorption: clarification and recommendation of terminology," Journal of Pharmacokinetics and Pharmacodynamics, 28(1), 3-6, 2001.

[20] Y. H. Zhao, M. H. Abraham, J. Le, A. Hersey, C. N. Luscombe, G. Beck, B. Sherborne, I. Cooper, "Rate-limited steps of human oral absorption and QSAR studies," Pharmaceutical Research, 19(10), 1446-1457, 2002.

[21] F. Montanari, G. F. Ecker, "Prediction of drug-ABC-transporter interaction-Recent advances and future challenges," Advanced Drug Delivery Reviews, 86, 17-26, 2015. 